\title{
Nordiques
}

38 | 2019

Le petit héros scandinave

\section{Rasmus på luffen by Astrid Lindgren as a tale of adoption and a tale of creation}

\section{Massimo Ciaravolo}

\section{(2) OpenEdition \\ 12 Journals}

Electronic version

URL: http://journals.openedition.org/nordiques/288

DOI: $10.4000 /$ nordiques.288

ISSN: $2777-8479$

Publisher:

Association Norden, Bibliothèque de Caen la mer

\section{Printed version}

Date of publication: 1 November 2019

Number of pages: $31-42$

ISBN: 979-1-0959140-4-4

ISSN: 1761-7677

Electronic reference

Massimo Ciaravolo, "Rasmus på luffen by Astrid Lindgren as a tale of adoption and a tale of creation", Nordiques [Online], 38 | 2019, Online since 31 October 2020, connection on 14 March 2021. URL: http:// journals.openedition.org/nordiques/288 ; DOI: https://doi.org/10.4000/nordiques.288 


\section{Rasmus på luffen by Astrid Lindgren as a tale of adoption and a tale of creation}

Massimo Ciaravolo*

\section{RÉSUMÉ}

Le roman d'Astrid Lindgren, Rasmus på luffen (Rasmus et le vagabond), publié en Suède en 1956, décrit l'histoire du jeune Rasmus qui s'échappe de l'orphelinat où il a grandi. Il rencontre le vagabond Oskar lors de son errance dans la campagne suédoise pendant l'été et trouve enfin une maison. Dans cet article, nous soutenons l'hypothèse qu'il s'agit d'une histoire d'adoption et de création dans laquelle l'action se déroule sur sept jours. Ces aspects sont intimement liés : on peut compter les jours et les nuits car la narration relate les moments où Rasmus s'endort et se réveille, ce qui est lié avec la peur fondamentale du petit héros d'être abandonné et la joie de découvrir qu'il ne l'est pas. Sans pousser l'analogie avec la Genèse, il est tout de même vrai qu'une nouvelle vie et un nouveau monde se dessinent pour Rasmus et pour son père Oskar. La représentation chaleureuse et hérö̈que propre à Lindgren du "luffare ", le clochard dans la Suède rurale traditionnelle, s'appuie sur des souvenirs personnels et des modèles littéraires, adaptés aux besoins de la littérature pour enfants.

\section{ABSTRACT}

Astrid Lindgren's novel Rasmus på luffen (Rasmus and the Vagabond), published in Sweden in 1956, deals with the boy Rasmus who escapes from an orphanage where he has spent his life, meets the tramp Oskar wandering in the Swedish countryside during the summer and finally finds a home. I argue that it is a tale of adoption as well as of creation, as the action lasts seven days. The aspects are intertwined: one can count the days and nights, because the tale records when Rasmus falls asleep and wakes up, which is connected with the protagonist's fundamental fear of being abandoned, and the joyful awareness that he has not. Without pushing the analogy with the Genesis too far, it is true that a new life and a new world are emerging for both Rasmus and his father Oskar. Lindgren's warm and heroic representation of the luffare, the tramp in traditional rural Sweden, draws on personal memories and literary models, though adapted to the needs of children's literature.

\footnotetext{
* Massimo Ciaravolo est Professeur Associé au département d'études scandinaves de l'université Ca' Foscari à Venise. Ses recherches portent principalement sur August Strindberg, la modernité dans la littérature scandinave à l'aube du XXe siècle et la littérature prolétarienne en Suède dans les années 1930.
} 


\section{DURATION OF THE STORY}

Astrid Lindgren's novel Rasmus på luffen (Rasmus and the Vagabond or Rasmus and the Tramp in English translation) was published in Sweden in 1956. It deals with nine-year-old Rasmus who runs away from Västerhaga orphanage, where he has spent all his life. He meets the tramp Oskar in the countryside and joins him, and together they embark on a series of adventures ${ }^{1}$. The American scholar Eva-Maria Metcalf underscores, in a rich and valuable monograph, the combination of freedom and security that the family atmosphere and the environment in rural Småland gave Astrid Ericsson (Lindgren) as a child. Metcalf describes also how Lindgren as a writer is able to translate this happy combination in many of her stories, where "a safety net of loving relationship" compensates for dangerous and thrilling situations ${ }^{2}$. Consequently, Metcalf summarizes the plot of Rasmus påluffen:

In Rasmus and the Vagabond, Rasmus, who spends a few free and exciting summer weeks together with a tramp named Oscar [sic] after escaping from an orphanage, also finds the security of the safe and loving home he had been longing for when he and the tramp finally end up at Oscar's little cottage ${ }^{3}$.

The description sketches the fundamental theme of adoption, but Metcalf makes also a mistake concerning the duration of the story, which needs revision. The fourteen chapters of the book do not cover "a few summer weeks" but a shorter and crucial time of seven days. To my knowledge, this circumstance has not been observed or analysed before.

\section{A WEEK OF CREATION}

The fact that one can count the days and nights is not the result of an abstract or instrumental close reading. It is rather natural to focus on the temporal dimension when reading the novel, because it presents a tight action whereby days and nights follow each other without interruptions or long ellipses; time markers are

1 Astrid Lindgren, Rasmus på luffen, omslag och illustrationer av Eric Palmquist, Stockholm, Rabén \& Sjögren, 1956. The English translation I have used is Astrid Lindgren, Rasmus and the Vagabond, transl. by Gerry Bothmer, New York, The Viking Press, 1960.

2 Eva-Maria Metcalf, Astrid Lindgren, New York, Twayne Publishers, 1995, p. 3-4, p. 29-61; here in particular p. 32. The idea of freedom (frihet) and security (trygghet) as complementary for children's development refers to a well-known description given by Lindgren in the memoirs dedicated to her parents and her own childhood, originally published in 1973 : Astrid Lindgren, "Samuel August från Sevedstorp och Hanna i Hult", in Astrid Lindgren, Samuel August från Sevedstorp och Hanna i Hult. Barndomsminnen och essäer, Stockholm, Rabén \& Sjögren, 1999 [1975], p. 9-47; here in particular p. 41-44.

3 Eva-Maria Metcalf, Astrid Lindgren, op. cit., p. 49. 
frequent ${ }^{4}$. One reason is that Rasmus på luffen is also a detective story, in which the protagonist acts as a boy sleuth, who manages, with Oskar's help, to unmask two dangerous criminals. The thrilling events can take place at day or, quite often, during the white Swedish summer nights.

Another and equally important reason for the day-and-night sequence is of a more emotional kind, and it relates to the theme of adoption. The critical moments when Rasmus falls asleep and wakes up are carefully recorded in the story. When falling asleep, Rasmus is afraid of being abandoned; he feels joy when he wakes up and realizes that he has not, and that someone new, devoted and reliable, the tramp Oskar, is near him; in contrast, unspeakable terror fills Rasmus when Oskar is taken away from him.

In this respect, I argue that the sequence of seven days and six nights is an important feature, if we read this realistic story at a more symbolic level, as a tale of adoption and of creation. Even if one does not want to push the analogy with the Genesis too far, it is true that during this time span a new life and a new world take shape for both Rasmus and Oskar, his father-to-be.

\section{Lindgren's Christian LEgaCY}

Does Lindgren consciously refer to the Genesis, or is this just a possible association in a reader's mind? There is, in my opinion, enough evidence of a conscious reference to this central myth of the Jewish-Christian tradition in the text, and I am going to focus on it. One thing is sure: Christian values are part of Lindgren's rural legacy and family history, as much as her progressive views and enlightened modernity are. It might not be self-evident to a non-Scandinavian reader that different currents and worldviews contributed to the construction of Sweden's "modern project". The rural culture, with its Christian legacy, was as important as the urban, liberal currents were, and they all interacted and cooperated with the larger social democratic movement. Astrid Lindgren's long life in the twentieth century and her career as a writer and an intellectual epitomize this combination. Her parents were the tenant farmers of a parsonage (prästgaird); references to the Bible, the Gospels, Christian hymns and prayers abound in her works. In her autobiographical writings, she tells us about her parents' faith and about the

4 As regards order and duration in narrative discourse, see Gérard Genette's Figures 3, Paris, Seuil, 1972, p. 77-144. Concerning the importance of applying narratological principles also to children's literature, see Maria Nikolajeva, Barnbokens byggklossar, Lund, Studentlitteratur, 2017 [1998]; in particular about temporality, p. 315-344. 
strong Christian elements in her upbringing; and she can do it with a peculiar mixture of deep, nostalgic involvement and modern, ironic distance 5 .

\section{FALLING ASLEEP BY A TRAMP'S SIDE}

Before examining the religious dimensions in Rasmus på luffen, I would like to consider the motif of falling asleep, in order to highlight the bond of affection that is uniting the boy and his adult counterpart from the start. On the third day of the story - which is also Rasmus' first day with Oskar, corresponding to chapters 4 and 5 - Oskar allows Rasmus to take a long nap in the daytime along the way, when the sun is warm. Rasmus escaped from the orphanage just the night before and he did not get much sleep. He and the tramp met the following morning in a small barn in the countryside, where they both had found refuge. The description of Rasmus' first hours as a tramp in chapter 4 is full of interesting details. Rasmus discovers, with joy and surprise, how beautiful it is to be a tramp, and the art of leisure that a tramp's life requires: you do not have to hurry and you can possess the whole world with your gaze. Rasmus is however too tired to continue walking for a long time:

"You can sleep here for a while," said Oscar. "There's shelter and sun here and no one can see you from the road."

Rasmus began to yawn but a terrible thought made him stop with his mouth wide open. "Oscar, you promise not to go away while I'm asleep?"

Oscar nodded. "Just you go ahead and sleep," he said.

Rasmus threw himself down on his stomach and burrowed his nose into the fold of his sleeve. The sun warmed him so wonderfully and he was so sleepy. As he was sinking deeper and deeper, he felt Oscar spreading his jacket over him. Now he wasn't cold any longer ${ }^{6}$.

\section{THE HAWK AND THE CUCKOO}

In an inspiring book, the Norwegian scholars Jørgen Gaare and Øystein Sjaastad explore the aesthetical, ethical, philosophical and religious dimensions of Astrid Lindgren's oeuvre, offering a series of penetrating observations concerning

5 See Astrid Lindgren, "Samuel August från Sevedstorp och Hanna i Hult", op. cit., and Astrid Lindgren, "Minnes..." ("I Remember..."), also in Astrid Lindgren, Samuel August från Sevedstorp och Hanna i Hult, p. 49-77. In English: Astrid Lindgren, "I Remember...", transl. by Patricia Crampton, Signal, n ${ }^{\circ}$ 57, 1988, p. 155-169.

6 Astrid Lindgren, Rasmus and the Vagabond, p. 58-59; Astrid Lindgren, Rasmus på luffen, p. 53. : “- Här kan du knyta dej, sa Oskar. Här är det lä och sol, och ingen käft kan se dej från vägen. Rasmus gäspade, men en orolig tanke fick honom att komma av sig mitt i gäspningen. / - Oskar, det är väl säkert, att du inte går ifrån mej, när jag sover? / Oskar skakade på huvudet. - Sov du, sa han bara. / Rasmus kastade sig ner på marken. Han la sig på magen och borrade in näsan i ena armvecket. Solen värmde så skönt, han kände sig så dåsig. Halvt i sömn märkte han, att Oskar bredde sin kavaj över honom. Nu frös han inte längre." 
Rasmus pa luffen ${ }^{7}$. The opposition between good and evil, between the loveless and for Rasmus humiliating and annihilating life at the orphanage and the tramp's goodness and empathy, is also expressed through the opposition between two birds, the hawk and the cuckoo, which are similar in spelling and pronunciation in Swedish ( $b \ddot{o k}$ and gök). The name of the headmistress at the orphanage is Fröken Hök, Miss Hawk. Her emotional coldness is what mostly terrifies Rasmus. He and his mates at the orphanage often call her Höken, "The Hawk", and so does the sympathetic narrator. Once Rasmus even addresses her, by a slip of the tongue, as "Höken Frök", and feels ashamed and terrified for that ${ }^{8}$. The tramp Oskar is, in contrast, a warm-hearted and funny chap, who gives himself a series of nicknames. As he begs for money, singing songs as a summer tramp, he calls himself a cuckoo, but more precisely (and rather astonishingly for Rasmus) "Guds rätte gök", literally "God's right cuckoo". There is undoubtedly something divine about a singing tramp who instinctively cannot stand injustice and protects the child, and who amusingly dismisses the farmers' reproaches, when he begs instead of working. If a cuckoo becomes a hawk in autumn, according to a Swedish popular belief mentioned in the novel, our Oskar is, in contrast, not so changeable. It would be unbearable for Rasmus if good suddenly turned to evil ${ }^{1}$. In this sense, Oskar proves to be a particular cuckoo, divine and fair, steady and reliable in his feelings for Rasmus ${ }^{10}$.

Oskar is the one who explicitly mentions the divine act of creation. He explains to Rasmus why, according to him, God includes tramps in his plan and wants them to have a place in the universe : hence his names "Paradis-Oskar" and "Guds rätte gök":

"Tramp is right... Haven't you heard of Paradise Oscar? That's me. The paradise tramp and God's best friend, that's me."

7 Jørgen Gaare, Øystein Sjaastad, Pippi og Sokrates. Filosofiske vandringer i Astrid Lindgrens verden, Oslo, C. Huitfeldt Forlag, 2000, p. 80-87, p. 399-408.

8 In chapter 3. Astrid Lindgren, Rasmus på luffen, p. 31. Astrid Lindgren, Rasmus and the Vagabond, p. 35 .

9 Astrid Lindgren, Rasmus på luffen, p. 61-62. Astrid Lindgren, Rasmus and the Vagabond, p. 68. Cf. "Gök", fageln.se. En fågelbok på nätet, <http://www.fageln.se/art/goek.aspx> (06/01/2019); and Eva Wigström, Folkdiktning, visor, folktro, sägner och en svartkonstsbok. Andra samlingen, Göteborg, Torsten Hedlunds förlag, 1881, p. 270, Projekt Runeberg <http://runeberg.org/wefolkdik2/0278.html> (06/01/2019).

10 In the discussion after my paper, at the université de Haute Alsace in Mulhouse on September 21, 2018, other interesting associations were proposed. Annelie Jarl Ireman (université Caen-Normandie) pointed out that one could see Oskar as a "cuckoo" also in the sense that he, as a tramp, visits other people's home, without having his own "nest". Harri Veivo (université Caen-Normandie) observed, on the other hand, that the "cuckoo's son" means an intruder in someone else's home in Finnish folklore, whereas our cuckoo Oskar behaves differently, finally welcoming the orphan Rasmus into his home and adopting him. 
God's best friend! Rasmus began to wonder if that tramp was all right in the head. "Why are you God's best friend?" asked Rasmus.

Many deep wrinkles appeared on Oscar's forehead. "Someone has to be, what's more there has to be a tramp who is God's best friend. God approves of tramps."

"Does he?" said Rasmus suspiciously.

"Yes he does," Oscar assured him. "When he has gone to so much trouble to put the world together he wants to have everything in it. Don't you understand? How would it look if there was everything except tramps? "

Oscar nodded, apparently pleased with his explanation. "God's best friend, yes sir, that's me." ${ }^{11}$

\section{OSCAR VERSUS OSKAR}

When Rasmus escaped from the orphanage the night before, he could not help stopping by to cast a last glance at Miss Hawk's room from the outside. From there he saw, on the walls of the room, a picture of Jesus Christ in front of Pontius Pilate and a picture of the Swedish royal family. That the action of Rasmus pa luffen, set in rural Sweden, takes place during the reign of king Oscar II, i.e. at the turn of the nineteenth and twentieth centuries and before 1907, is indicated by some references that provide historical markers. At the beginning of chapter 2, children at Västerhaga get nervously ready for the visit of a couple who is going to choose "their" child. Rasmus scrubs himself with particular zeal, but Store-Peter, who is almost thirteen and knows that no one will choose him, is cynical and refuses to wash himself. When Rasmus tells him "[d]u vet vem som kommer", Store-Peter replies "[d]u tror visst att det är kung Oscar livs levande"12. This detail can also work as a hidden prolepsis, or flash-forward, as Rasmus is really

11 Astrid Lindgren, Rasmus and the Vagabond, p. 52; Astrid Lindgren, Rasmus pa luffen, p. 47. : “- Luffare, sa du... har du hört talas om Paradis-Oskar nån gång? Det är jag det. Paradisets luffare och Guds rätte gök, det är jag det. / Guds rätte gök! Rasmus började undra, om den där luffaren var riktigt klok. / - Varför är Oskar Guds rätte gök, frågade han. / Oskar runkade djupsinnigt på huvudet. / - Nån ska vara det också. Det måste finnas nån som går på luffen också och är Guds rätte gök. Gud vill att det ska finnas luffare. / - Vill han, sa Rasmus misstroget. / - Det vill han, försäkrade Oskar. När han har gjort sej så mycket besvär och suttit och knåpat ihop hela jorden, så vill han att allting ska finnas, begriper du väl. Och hur skulle det se ut, om allting fanns utom just luffare? / Oskar nickade belåtet. / - Guds rätte gök - jojomen!". Gerry Bothmer's translation is problematic here, because it domesticates the text, reducing or eliminating elements of linguistic and cultural otherness. As we have seen, the cuckoo is an important symbolic marker in the tale, and there is no point in eliminating it as too odd, because even Rasmus, as the most immediate child narratee, must find the expression peculiar. Eva-Maria Metcalf, Astrid Lindgren, p. 32-33, offers interesting notes as to the alterations and omissions in the American translations of Lindgren's books. About "domestication" in translation, especially seen from the point of view of the USA as target culture, see Laurence Venuti, The Translator's Invisibility. A History of Translation, London, Routledge, 1995.

12 Astrid Lindgren, Rasmus på luffen, p. 18. Astrid Lindgren, Rasmus and the Vagabond, p. 21 : “"[y] ou know who is coming." / "You seem to think that it's old king Oscar come back to life". Bothmer intends livs levande (in person) as if King Oscar of Sweden were coming back to life from the dead. It is not a correct translation of the expression. 
going to meet his "Oscar". In a similar fashion, the tramp Oskar refers to queen Sofia, Oscar II's wife, and to the royal family in chapter $5^{13}$. At the beginning of chapter 3, when the two adoptive parents have finally visited Västerhaga, chosen their girl with curly hair and gone, the disappointed boys comment on their visit. Store-Peter sardonically imitates the rich lady's attempts to approach the children with questions: "Har du sett nån sån där attemobil nån gång?" 14. Altogether, one can guess that the story of Rasmus på luffen takes place at the beginning of the twentieth century, when cars have already appeared, and king Oscar II and queen Sofia are still reigning over Sweden.

Our tramp hero is also named Oskar, like the Swedish king (although spelt with $/ \mathrm{k} /$ and not with $/ \mathrm{c} /$ ), but in addition to that he calls himself, as we have seen, Paradis-Oskar. His sphere of power is evidently opposed to the Swedish monarch's official power. He belongs to leisure and summer, and to a promise of affective bonds, home and happiness, that is guiding Rasmus and the tramp's steps in the right direction. In short, the tramp Oskar is a different kind of king: he is a bearer of authentic evangelical values, opposed to the stiff, institutional Christian religion and devotion to the monarchy, embodied by Miss Hawk, who pays visits to the priest and sings hymns. Oskar can respond to the child's emotional and affective needs, and he is even able to change his perspective radically during the novel, accepting Rasmus as a son and the obligations that his new fatherhood entail, even if that means giving up part of his freedom. To be sure, the story is told from Rasmus' point of view, and the readers can observe Oskar only from the outside; to an adult reader (maybe especially one who is considering adopting a child), however, it seems as if Oskar is preparing for fatherhood without even being aware of it, not until he meets Rasmus.

In chapter 5, still on the third day, Oskar and Rasmus stop at a lake to take a bath. Such baths were a practical need for the Scandinavian tramps wandering in the countryside, if they wanted to keep themselves clean. This realistic episode can however also be read as a symbolic and religious rite of passage and rebirth ${ }^{15}$.

13 Astrid Lindgren, Rasmus på luffen, p. 63. Cf. Astrid Lindgren, Rasmus and the Vagabond, p. 69, where the original expression "drottning Sofias namndag" is changed into "the queen's name day".

14 Astrid Lindgren, Rasmus på luffen, p. 30. Astrid Lindgren, Rasmus and the Vagabond, p. 34: "Have you ever seen an automobile?". In the Swedish original text, the spelling of "automobile" is altered in a funny way, conveying the idea that the product is rather new.

15 In the discussion after the paper, Joachim Grage (Albert-Ludwigs-Universität Freiburg) observed that water is central also in the third day of the Genesis, when God creates the sea. Grage also suggested that the initial situation Rasmus experiences at the orphanage (lack of love and annihilation) could refer to the chaos prior to the Creation of the universe in the Genesis. 
The fact that Rasmus cannot repress his emotions during the bath indicates that it has been an intense spiritual experience, not only a matter of personal hygiene:

Sitting on a rock, he [Oskar] carefully washed his feet and then waded back to the shore in his wet pants, singing a snatch of a song to himself about summer and sun and swimming in the sea.

"Oscar, I like you," Rasmus shouted after him, and he didn't know himself what made him do it just then ${ }^{16}$.

The emphasis on affective bonds recurs again in chapter 11, on the fifth day, when Rasmus, after a dream at night, composes his first nonsense song with the help of his master, the divine cuckoo Oskar; it is the famous song of the dream of the kitten that only ate herrings and potatoes. Even artistic creativity becomes a ground for mutual understanding and affection: a "world creation", as it were, as beautifully demonstrated by the black-and-white film version of this episode. Luffaren och Rasmus (The Tramp and Rasmus) came out in 1955, one year before the novel, and was based on Lindgren's manuscript ${ }^{17}$.

\section{INTERWEAVING ADOPTION, DETECTION AND VAGABOND LIFE}

As Vivi Edström has observed, Lindgren can borrow patterns from the myth, the legend and the fairy tale and adapt them to her needs. In this case she can also borrow from literary models of the runaway orphan boy who is finally recognized and finds home ${ }^{18}$. Lindgren can however enrich these patterns and models through a more complex and progressive pedagogical awareness, which fully belongs to the twentieth century. Her children are allowed to express strong emotions, whether they burst out laughing or into tears, and this differs in fact from the linear and flat dimension of the fairy tale, which is a pure action void of

16 Astrid Lindgren, Rasmus and the Vagabond, p. 69-70; Astrid Lindgren, Rasmus på luffen, p. 63.: "Sittande på en sten tvättade han [Oskar] grundligt sina fötter och klafsade sedan tillbaka upp på stranden i sina våta byxor, medan han halvhögt sjöng för sig själv: / - Nu är det sommar, / nu är det sol, / nu får man bada i sjöngen... / - Oskar, jag tycker om dej, skrek Rasmus efter honom och visste inte själv, varför han sa det just då." Even in this passage, domestication in translation is evident, as the verses of Oskar's song are paraphrased. In addition, the translation reduces the emotional impact of "jag tycker om dig", which does mean in Swedish "I like you", but also "I love you".

17 Luffaren och Rasmus, directed by Rolf Husberg, with Åke Grönberg and Eskil Dalenius in the main roles as Oskar and Rasmus. I have not been able to see the whole film, but the mentioned episode is available on YouTube: "Luffaren och Rasmus: Kattvisan (Tänk jag drömde I natt)", <https://www. youtube.com/watch?v=2aqJX4PKpdI> (06/01/2019). The novel Rasmus på luffen is based on the film manuscript. About the connection between the film production and the novel, see Jens Andersen, Denna dagen, ett liv, Stockholm, Norstedts, 2014, p. 278-282.

18 Vivi Edström, Astrid Lindgren. Vildtoring och lägereld, Stockholm, Rabén \& Sjögren, 1992; in particular about Rasmus på luffen p. 46-51. 
feelings ${ }^{19}$. Furthermore, as Marianne Novy has pointed out, "most of the adoptees in canonical literature, fairy tales and folklore find their identity by meeting their birth parents" 20 , whereas Lindgren remarkably focuses on the process of adoption, in which children and parents have to invent themselves into new roles and a new affective bond without a biological basis.

Charlotte Beyer underscores the "dual focus on adventure and affect" in Rasmus på luffen, and she points out that the thriller genre, with its central character, the boy detective, reinforces Rasmus' existential quest for identity, self-knowledge, meaning and justice ${ }^{21}$. The thriller, I argue, reinforces the luffare motif as well, since the Swedish tramps were in a socially weak and marginalized position, and suspicions immediately fell upon them if crimes were committed. Lindgren renders this historical circumstance with accuracy, and it becomes of paramount importance in the story, because Rasmus' life is literally at stake when Oskar is persecuted and imprisoned for crimes he has not committed. Thus, the three main motifs of the novel - adoption, detection and vagabond life - are interwoven with great literary mastery.

\section{The SCANDINAVIAN TRAMPS, a LITERARY TREASURE}

Rasmus pa luffen draws on the author's memories and experiences in more than one respect. The visits of tramps asking for food and lodging were frequent at her farm during her childhood. Lindgren has written about it in the autobiographical essay "Minnes..."22 and in the story "God natt, Herr luffare!" (Good Night, Mr. Vagabond!) ${ }^{23}$. In addition, the painful experiences of having to hide her first pregnancy because of the scandal of an extramarital relation, and having to leave her baby son to a foster family in Copenhagen for some time, have marked Lindgren's life and authorship profoundly, as pointed out by her biographers ${ }^{24}$. These experiences have given the author a more acute awareness of children's needs, of the complicated emotional and affective bonds between children and parents, as well as of the conflicts of loyalty to different kinds of parents.

19 Cf. Vladimir Propp, Morphology of the Folktale, transl. By Laurence Scott, Austin, University of Texas Press, 1968 [1958], and Max Lüthi, The European Folktale. Form and Nature, transl. by John D. Niles, Bloomington, Indiana University Press, 1986.

20 Cit. in Charlotte Beyer, "Adventures and Affect. The Character of the Boy Detective and Orphan in Astrid Lindgren's Rasmus and the Tramp", in Michael G. Cornelius (ed.), The Boy Detectives. Essays on the Hardy Boys and Others, Jefferson (North Carolina) and London, McFarland \& Company, 2010, p. 125.

21 Ibid., p. 120-131.

22 Astrid Lindgren, "Minnes...", p. 57-58.

23 Astrid Lindgren, "Godnatt, herr luffare!", in Astrid Lindgren, Kajsa Kavat och andra barn, Stockholm, Rabén \& Sjögren, 1950, p. 134-148.

24 Margareta Strömstedt, Astrid Lindgren. En levnadsteckning, Stockholm, Rabén \& Sjögren, 2017 [1977], p. 175-182; Jens Andersen, Denna dagen, ett liv, p. 79-119 
Wanderers, vagabonds and tramps in the rural areas of Scandinavia, with their peculiar way of life, are frequent motifs in the literature of the first half of the twentieth century. Literature helps to rescue and fix, as cultural memory, a collective, popular and oral memory of traditional life, which modernity is sweeping away. As an author, Astrid Lindgren can take on that legacy, and she finds inspiration in both the collective memory of her own family and her province and in the written memory of previous writers. In this respect, Rasmus pa luffen can be compared to other masterpieces of Scandinavian prose such as Johannes V. Jensen's Himmerlandshistorier in Denmark (basically three collections published in 1898, 1904 and 1910)25, Knut Hamsun's novel trilogy about the wanderer Knut Pedersen in Norway (1906, 1909 and 1912) ${ }^{26}$, and Harry Martinson's novel Vägen till Klockrike (The Road) in Sweden (1948) ${ }^{27}$. A common trait uniting the mentioned writers, Lindgren included, is that they all retain a strong sense of premodern life in Scandinavia, which was part of their childhood, but they are also on the threshold of a problematic modernity, which they all have to come to terms with in one way or another.

There is, for example, a special understanding between children and vagabonds in Jensen's stories. The village children love Lindby-Skytten, the Lindby Hunter, one of the memorable vagabond heroes in Himmerlandshistorier ${ }^{28}$; and another special vagabond, Tordenkalven, is well known for his songs ${ }^{29}$. Furthermore, echoes of Hamsun's and Martinson's wanderers recur in Rasmus på luffen; Hamsun's autobiographical protagonist Knut Pedersen displays an unruly character and an urge to live in touch with nature and the elements, and the same applies to Martinson's Bolle. In a more gentle form, adapted to children's literature, the vagabond's typical restlessness returns in Paradis-Oskar. Even "Luffarvisan", The Tramp's song, composed by Lindgren in connection with her novel, can interpret and renew these recurring traits of vagabond life, as they are represented in modern Scandinavian literature. Finally, Martinson can read the tramps' restlessness from a social and historical perspective, i.e. in relation to the age of world mobility and migration they lived in. The motif of Swedish migration to America is as relevant in Rasmus pa luffen as it is in Vägen till Klockrike, not to mention Jensen's and Hamsun's works. The dramatic chase, during which Oskar and Rasmus face the two rascals Lif and Liander, in order to affirm justice and to

25 Johannes V. Jensen, Himmerlandshistorier, 1-2, ed. by Per Dahl, Aage Jørgensen, København, Gyldendal, 2018. This critical edition contains also the stories that the author added at a later stage.

26 Knut Hamsun, "Under høststjernen", in Knut Hamsun, Samlede Verker, 5: Svermere. Under høststjernen, Oslo, Gyldendal Norsk Forlag, 2007, p. 93-206; Knut Hamsun, Samlede Verker, 7: En vandrer spiller med sordin. Den siste glede, Oslo, Gyldendal Norsk Forlag, 2008.

27 Harry Martinson, Vägen till Klockrike, Stockholm, Bonniers, 1998.

28 Johannes V. Jensen, “Lindby-Skytten”, in Johannes V. Jensen, Himmerlandshistorier, 1, p. 53-62.

29 Ibid., p. 225-231. 
save their lives, takes place in a village that its former inhabitants have deserted, when they all migrated to Minnesota ${ }^{30}$.

As I said, Lindgren's warm representation of the Swedish luffare adapts social reality to the needs and purposes of children's literature. How historically reliable her depiction is, can be observed through a comparison with Martinson's novel Vägen till Klockrike, a masterly literary sociology of nomadic life ${ }^{31}$, and even with later works of historians such as Birger Magnusson in Sweden ${ }^{32}$ and Thor Gotaas in Norway ${ }^{33}$. These sources show that social reality could be sordid and painful for tramps, and not at all so glorious. I have already mentioned the circumstance of bias and discrimination against tramps, which drew suspicions on them in case crimes were committed in an area. Vägen till Klockrike, a novel for adults, offers a particularly complex and gloomy picture of the protagonist Bolle's nomadic urge. Bolle suffers from the same disciplinary order, the humiliating reproaches by the working farmers, and the general bias against tramps as Paradis-Oskar does. The children's hero Paradis-Oskar has, however, a resource in his witty humour, when replying to the farmers, and in his courage, when criticizing the police for their prejudice against tramps. This mood saves him from the depressive and melancholic tendencies that affect Bolle. There is another fundamental difference. Bolle is a so-called "professional" tramp (yrkesluffare), who has decided to wander and beg even in wintertime, enduring cold, hunger and hardship, and breaking away from the rules of ordinary people. In the end, Paradis-Oskar proves to be, in contrast, a seasonal tramp (more similar, in this respect, to Hamsun's wanderer Knut Pedersen, and to what Martinson's hard-boiled, professional tramps would call a "romantic" tramp ${ }^{34}$ ). Oskar is actually a crofter (torpare) with a home and a wife, Martina. When spring comes, he simply cannot stand still and has to wander for some time.

\section{FREEDOM AND SECURITY}

With Oskar, Rasmus has therefore won both the security of a home and the promise of freedom that life as a tramp can give. A final segment of the

30 Chapters 9 and 10, corresponding to the fourth day and the fourth night. Astrid Lindgren, Rasmus på luffen, p. 101-126. Astrid Lindgren, Rasmus and the Vagabond, p. 109-135.

31 Cf. Massimo Ciaravolo, "Harry Martinson's Prose Nomadism. A Comparative Reading of Resor utan mål, Kap Farväl!', and Vägen till Klockrike”, in Anna Maria Segala, Paolo Marelli, Davide Finco (eds), The Nordic Avant-gardes in the European Context of the Early $20^{\text {th }}$ Century, Bari, Edizioni di Pagina, 2017, p. 226-242.

32 Birger Magnusson, Trådarbetande luffare, Mjölby, Artemi, 2006 [1997], and Birger Magnusson, Luffare, original \& luffarkåkar, Mjölby, Artemi, 2006 [1998].

33 Thor Gotaas, Pa loffen. Landstrykere og vagabonder langs norske landeveier, Oslo, Spartacus, 2001.

34 See the chapter "De romantiska" (The Romantic Ones) in Harry Martinson, Vägen till Klockrike, p. $253-257$. 
plot reinforces the themes of adoption and affective bonds as "world creation". Rasmus experiences a troubled last night - his sixth one in the novel - when his cherished hope of being adopted by wealthy people suddenly seems to come true. Oskar works for a good couple of rich farmers who would like to adopt a child. Rasmus thus spends the night with them, in a home that might become his. In actual fact, he falls into despair, as he realizes for the first time how much he loves and needs Oskar as a father, no matter how wealthy he could become as the farmers' heir. The adults, both Oskar and the farmers, follow this process carefully and respectfully, well aware that Rasmus' first night without Oskar is just a test. Once the test has given a clear outcome, the rich farmers decide to go to Västerhaga orphanage, to adopt another child instead. At this point, Rasmus dreams of a reunion with Gunnar, his best friend, the only person he regretted leaving there when he fled, and he suggests that the couple should take him. The happy conclusion would be complete for Rasmus with the possibility of having his best friend Gunnar back as a neighbour. Incidentally, the circumstance also shows that life at Västerhaga was not only a total deprivation, a "chaos" prior to creation according to the Genesis pattern I have outlined (see in particular note 15). If there was one valuable thing about that life, it was Rasmus' friendship with Gunnar, which is absolutely worth rescuing into the new life.

\section{OUR NEED FOR AsTRID}

Let me conclude with an autobiographical note. I am an adoptive parent. For me and for my wife it was not easy to accept and "learn" adoptive parenthood after years of expectation and frustration. Along the way, I gained courage and insights thanks to Astrid Lindgren's books, in particular the fantasy novel Mio, min Mio (1954, Mio, my Son in English) and the realistic novel Rasmus på luffen, two different but equally profound tales of adoption. What Sonja Svensson points out in her beautiful article "Vart behov av Astrid" (Our need for Astrid), is the existential relevance of her authorship ${ }^{35}$. I have also experienced what Svensson observes: that reading Lindgren is important for our lives, and that her texts have become a source of energy for so many of us.

35 Sonja Svensson, "Vårt behov av Astrid”. Barnboken, vol. XXV, n 1, 2002, p. 3-13. 